Témoigner Témoigner. Entre histoire et mémoire

Getuigen Revue pluridisciplinaire de la Fondation Auschwitz

$125 \mid 2017$

Histoire et mémoire de la persécution des

homosexuel-le's par les nazis

\title{
Quand le bourreau prend la parole. Towards an ethics of perpetrator testimony? (Anneleen Spiessens)
}

\section{Catherine Gilbert}

\section{(2) OpenEdition \\ Journals}

Electronic version

URL: https://journals.openedition.org/temoigner/6272

DOI: $10.4000 /$ temoigner.6272

ISSN: 2506-6390

Publisher:

Éditions du Centre d'études et de documentation Mémoire d'Auschwitz, Éditions Kimé

Printed version

Date of publication: 1 October 2017

Number of pages: $35-39$

ISBN: 978-2-930953-01-4

ISSN: 2031-4183

Electronic reference

Catherine Gilbert, "Quand le bourreau prend la parole. Towards an ethics of perpetrator testimony?

(Anneleen Spiessens)", Témoigner. Entre histoire et mémoire [Online], 125 | 2017, Online since 24

December 2021, connection on 04 February 2022. URL: http://journals.openedition.org/temoigner/

6272 ; DOI: https://doi.org/10.4000/temoigner.6272 


\section{QUAND LE BOURREAU PREND LA PAROLE TOWARDS AN ETHICS OF PERPETRATOR TESTIMONY? \\ ANNELEEN SPIESSENS}

BOOK

$\mathrm{T}$ cts of the twentieth and early tweny-first centuries have given rise to a desire and perhaps even a necessity - to gathe at a fuller understanding of violent historical events. But what platform should perpetrators be given fom which to watus "witnes" as surve tow should we lisstatus of "witness" as survivors? How ten to, represent and respond to thei voices? In short, how can we ethically trators? Anneleen Spiesses of perpele ch to tacke these trobling cisely to tackle these troubling questus. from testimonial to the pury literfrom testimonial to the purely literrolo Holocaust and the 1994 Genocide gainst the Tutsin Rwanda. Throug cuestions the status of the "testi" its function is deterator and how its function is determined through range of editorial and translation deliberate decision to lay trae the heory - which is often used as a lens through whic to exan to sure side, choosing com the wity complex position of the writer-mediat. She rightly place in the presece of "tiers", and her focus on the

positioning of a range of mediators - writers, editors, translators - is original and productive, highlighting "les possibiltés d'un disco productive, hom "loix du boureau tout en proposant une résta éthique" ( 30 ). Without denying the risk ésistance with (p.30). Wint the public sphere Spiessens demonstrates testimonia literary texts are an integral part of

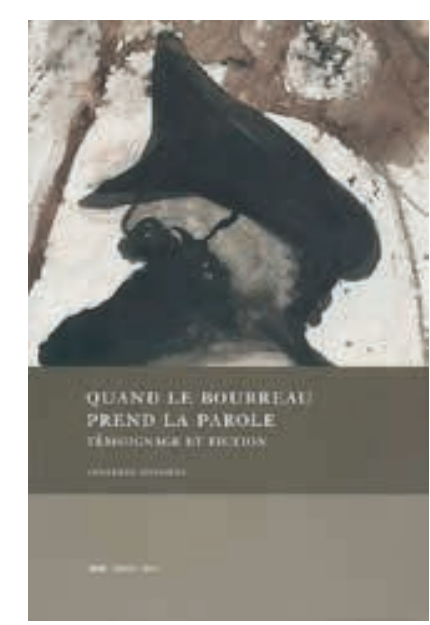
the "travail de mén ". follow o the "travail de mémoire" following a as they force us to ima event, insofar possibility of son with the of mass murder a humbection Following a short interpe Following a short introduction (Part 1) establishing the discursive setting of the parole du bourreau, two separate sections on the Shon (Part 2) and Rwand (Part 3). Part 2 (Pant 2) and Rwa (Part 3). Part 2 punolf Höss's memoirs dant in Auschwitz (1958), written dunt in Auschwitz (1958), witten during his imprisonment in Poland this opening chapter, Spiesil 1947. In this opening chapter, Spiessens use Höss presents himself as a credible historic witness, through a deliberate "mise en scène de soi" (p. 43) and through a deliberate "mise en scene de soi" (p. 43) and the public receiving his testimony A acceptable for tion tone and objective style, which ultimate reve moral ignorance. The reader is somewhat frustrated that these two passages, taken from the German text the ation, but these sam in the but phe chapter, when Spiessens compares the ways the passas both Brish and Ancan Englis. Indeed, the orig-

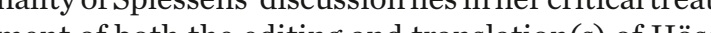
ment of both the editing and translation(s) of Hoss' of ". Spiessens" examines the ways in which a range

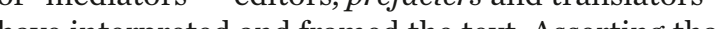

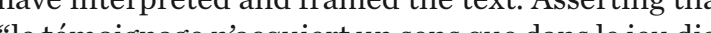
le ten logique entre narrateur, médiateur et lecteur" (p. 59), sinfluences the how tries and the recention of the text position the var. At issue in this chapter is the postion un "strateg of as they utilise "strategins of resistance whe trot preser. ", egling them to take a position ag thus reinforing the the a

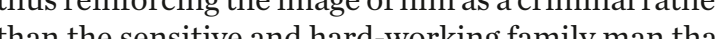
than the sensive a he presents hinself to be. In such cases, Spiessens are citic critical discourse and ethical resi of the perpetrator

In the second chapter in this section of the book Spiessens moves away from direct testimony to examin Row Written at a tim 1952 novel La Mort est mon métier. Written at a time when survivor testimonies were ceing very little attention, this novel is presented and anticin "era of the perpetrates" and anticipating the "era of the perpetrator" that ererins to interrogte the link thetween fiction siessens tory, questioning the importance of fidelity to reality tory, questioning the inportance of fidelity to reality and the ways in which literature can intervene in our unders cres chacter, Spiessens questions whether Merle's text his protagonist's psychological mevelopment creat

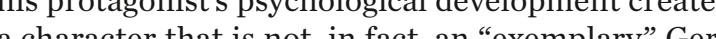
a character that is not, in fact, an "exemplary" Gerfigure (p. 149), which does not help us to understand how thousands of men participated in the crimes of the Nazi State Merlebecomes emblematic of Lanzmann' otion of the "obscenity of understanding", seeking to find clues in the individual's childhood that will enable us to understand their adult crimes. Spiessens argue that this "obscenity of understanding" should nevertheless not prevent us from considering the $p$ ossibity f the Holocaust nor from confronting the words of the perpetrators (p. 150).

Merle seems to suggest that literature can estab-

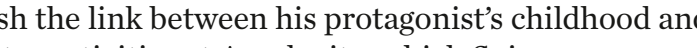
the major shortcoming Merle's text a tens sees as more 50 yom void in avoids in his prize-Winning novel Les Bienveillantes in the section on the Shoah. In this chapter, Spiesin the section on the Shoah. In this chapter, Spiesthe novel, fur the in the rem in the rencing of the novel's testimonial project, which she exmint in turn: presence (the presence of the witness at the ite of the even (t) distase (templ, the slogical) memory (real and manufactured), observation and, memory (real and manufactured), observachorimilien aue as a witness bush are simultanously rieded or as a winess through the novel. Spiessens' perceptive analysis reveals how the novel ppys with the limits of "testimony" the novel plays with the limits of "testimony" and "witbetween literature and historical reality; in Littell's novel, "le témoignage devient simulacre et l'histoire l'objet d'un jeu littéraire" (p. 199). For Spiessens, Littell's novel reveals itself to be an "imposible bok", whose ironic literary gam betwe ironic literary game precisely exposes the gap lights the inevitable failure of literature that seks approach historical reality in order to that seeks to deeper meaning.

Part 3 opens with an introduction to the genocide the Shoand a justification of the comparison with think the events of 1994. Three chapters then follow, the first of which is dedicated to five of the text witten as part of the 1998 Fest'Africa project "Rwanda: ten as part of the 1998 Fest'Africa project "Rwanda: Écrire par devoir de memoire. This chapter may the book as, unlike the texts the subject natter of 
œ ous section, the hybrid works under discussion are not primarily concerned with the point of view of the perpetrator. Nevertheless, the African authors under che

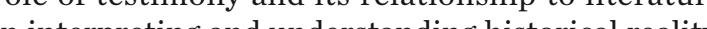
Through ang anderstanding "constorical reality. thrim a criticas ex thestinonies presented in the difers sens revals how these hybrid texts interrogate the problematic relationship betwex language and the genocidal violence that swept hirough the country in

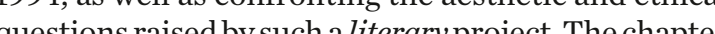
questions raised bysuch alterayproject. Thechapter writers "mediators" (écrivains "tiers") whose texts, writers as "mediators" (écrivains "liers") whose texts, as Spiessens rightly underlines, are assigned an important role in the construction of the memory of the gencide and the work of potic poetic expression and political action, underlining the importance ofthe "crivain intellecture in translating The fous of the next chater is Froader public.

The focus af the

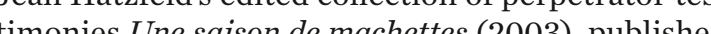
timonies Une saison de machettes (2003), published hat it is a the Fentens the "bourreau" into the rowing couces the figure the on the Rwanda the growng corpus of literathe on the Rwan questions raised in relation to the ethico-moral questions raised in relation to Hoss testimony: Is it justifiable to grant the perpetrator the the editor-writer-mediator push his project of underthe editor-witer-mediator push his project of understanding what happened from the point of view of the peed to reach a wider audience and bring to light the exp to rech a wider a experience ofgenocide, whilst at the same time voicing ords in the public spere we specific lon the specific language used - both by the perpetrators to shed light on this experience. She suggests the to shed light on this experience. She suggests that ument, particularly in terms of what we learn abocthe prepation of the gen or the we learn about the preparation of the genocide, the acts committed and the specific nature of the violence and cruelty. by the pens analysis of the "how" "rather than the "wh", revealing a absen of "traumatic memory". Reading this volume alongside Hatzfeld's earlier collection of survivor testimonies, Spiessens observes a crucial difference between the discourse of survivors and that of perpetrators, namely

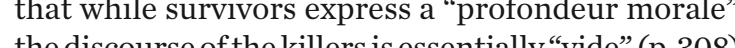
the discourse of the killersis essentially "vide" (p. 308) Of key interest here is Spiessens" examination of the paratextual elenents in the text, demonstrating how Hatzeld maintains his position of exteriority which enables him to judge and comment upon the words of his interlocutors. Like the editors/mediators of Höss' testimony, Hatzfeld himself formulates a connter disourse and maintains a position of resistance, particularly by using a deliberately poetic language that contrasts with the spoken language of the perpetrators. Spiessens also offers a fascinating discussion or the Dutch and Engish translations of diary voices that infiltrate the text The ways in which diary voices that infiltrate the text. The ways in which Hatzfeld intervenes in the text are nevertheless highly problematic, and Spiessens concludes that Hatzfeld himself does not demonstrate sufficient autore"flexivity nor acknowledgement of his position as an implicated" author-narrator (p. 345). While Hatzfeld himself clains a certain levelof objectivity, Spiessens convincingly argues that objectivity and impartiality are neither possible nor The fine perpetrator.

The final chapter focuses on Rwandan author Gilbert Gatore's Le Passé devant soi (2008), a text which claims its literary status as a novel and through which "la comprehension du génocide passe [...] par la forme etpar 'magination exclusivement" (p. 349). Spiessen again explores the language of the perpetrator and the role that is attributed to him in the novel. Among othe things, this language sheds light on the animality of the killers and their subsequent mutism, which Spiessen compares to the narrative mode and language used by the perpetrators in Hatzfeld's edited collection. Thi chapter offers an interrogation of the role of literature cide. It is use that the "intimate truth" of the genoto. In togecter as we begin to see how Rwandans directly affected by the genocide are beginning to use fiction to engage with this 'intimate truth". Yet Spiessens' analysis also reveals the ultimate impuissance of literature that sees itself as purely artistic when dealing with the subject of genocide, and we are left with a number of violence while refusing to take a position? Can the writer remain neutral or does the author need to be literature to surect the Gatore " de son "ve" (p. 375) which ultimately don politique

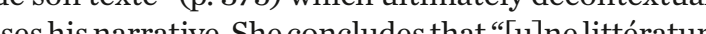
usuring éthiquequlaliàn ét (p. 376-377).

An Anglophone reader may be surprised at the apparent lack of justification of the choice of tex min Sehene's Le Feu sous la soutane (2005), spin to mind - Le rous la soutane (2005), spring to establishing the methodology at the beginning of the the hor of the subject and her textual a r

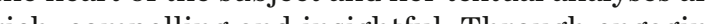
rich, compelling and insightful. Through engaging f testimony, Spiessens re-interrogates the relationship between writing and reality, between language. violence and representation. Drawing on a range of feoretical bases - from sociology to linguistics Spiessens' Quand le bourreau prend la parole is a rea and chle ling tyle, as well as the ritical power encted by form and style, as well as the critical power enacted by mediatory book is a in enty contion to the fields of book is a timely contribution to the fields of genocide, the book ethical dimension of working with perpetrator testiethical dimension of working with perpetrator test mony, a different set of ethical rules are needed so as not to betray the survivors moral status as witnesses, ing voice.

Catherine Gilbert (University of Oxford)
Learn more

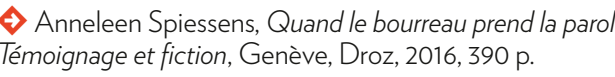

